\section{Association of maximal voluntary isometric handgrip strength with age, gender and handedness in older people}

\author{
JORDAN HERNÁNDEZ-MARTÍNEZ Z,a, DIEGO CISTERNA ${ }^{1, \mathrm{a},}$, \\ RODRIGO RAMÍREZ-CAMPILLO ${ }^{1, \mathrm{c}}$, CRISTIAN ÁLVAREZ $Z^{1, \mathrm{c}}$, \\ FRANCISCO GUEDE-ROJAS ${ }^{2, c}$, CARLOS DE LA FUENTE ${ }^{3,4,5, b}$, \\ MAURICIO CASTRO-SEPÚLVEDA ${ }^{6, b}$, JASON MORAN ${ }^{7, c}$
}

\section{ABSTRACT}

Background: Maximal voluntary isometric handgrip strength (MVIHS) is influenced by age, sex, and handedness. Aim: To assess the association of MVIHS with age, sex, and handedness in older adults. Material and Methods: MVIHS was measured using a digital dynamometer in 60 men and 60 women aged $73 \pm$ 6 years. Weight, height and handedness were also recorded. For analysis purposes, participants were divided into two age groups ( 65 to 70.9 years of age and $\geq 71$ years). Results: A negative correlation was observed between age and MVIHS in the non-dominant ( $r=-0.65$ and -0.59 in men and women, respectively) and dominant hands ( $r=-0.71$ and -0.64 in men and women, respectively). When age and MVIHS were correlated in the group aged 65-70 years, a significant correlation was observed in the non-dominant $(r=-045$ and -0.61 in men and women, respectively) and dominant hands $(r=-0.47$ and -0.64 in men and women, respectively). In the group aged $\geq 71$ years, a stronger correlation with age was also observed in the non-dominant ( $r=-0.92$ and -0.90 in men and women, respectively) and dominant hands $(r=-0.95$ and -0.90 in men and women, respectively). MVIHS was 2.8 to $8.9 \%$ lower in the non-dominant than in the dominant hand in all age groups. MVIHS was lower in women than in men in both age groups. Conclusions: MVIHS declines with age (especially after 71 years of age), is higher in men than women, and higher in the dominant than the non-dominant hand.

(Rev Med Chile 2018; 146: 1429-1437)

Key words: Frail Elderly; Geriatric Assessment; Muscle Strength; Sarcopenia; Resistance Training.

\section{Fuerza de agarre isométrica máxima en} relación a la edad, sexo y dominancia de mano

Antecedentes: La fuerza de agarre isométrica voluntaria máxima (FAIVM) puede verse influenciada por la edad, el sexo y la dominancia. Objetivo: Describir la FAIVM y su relación con la edad, el sexo y la dominancia en adultos mayores. Material y Métodos: La FAIVM, la masa corporal, la talla, y la dominancia fueron medidas mediante protocolos estandarizados en 60 hombres e igual número de mujeres que fueron divididos en dos grupos acorde a su edad (65 a
'Laboratory of Human

Performance. Quality of Life and Wellness Research Group. Departamento de Ciencias de la Actividad Física. Universidad de Los Lagos. Osorno, Chile. ${ }^{2}$ Facultad de Ciencias de la Rehabilitación. Universidad Andres Bello. Concepción, Chile. ${ }^{3}$ Carrera de Kinesiología. Departamento de Ciencias de la Salud. Facultad de Medicina. Pontificia Universidad Católica de Chile. Santiago, Chile.

${ }^{4}$ Laboratorio LIBFE. Escuela de Kinesiología. Universidad de los Andes, Santiago, Chile.

${ }^{5}$ Centro de Salud Deportivo, Clínica Santa María. Santiago, Chile.

${ }^{6}$ Facultad de Medicina. Universidad Finis Terrae, Santiago, Chile.

${ }^{7}$ Department of Sport, Hartpury University. Gloucestershire, UK. ${ }^{a} \mathrm{BSC}$.

${ }^{\mathrm{b}} \mathrm{MSc}$

CPhD.

Recibido el 14 de junio de 2018, aceptado el 19 de diciembre de 2018.

Corresponding Author: Rodrigo Ramírez-Campillo, PhD Departamento de Ciencias de la Actividad Física. Universidad de Los Lagos. Osorno, Chile. r.ramirez@ulagos.cl 
70,9 años, $y \geq 71$ años, respectivamente). Resultados: Se observó una correlación entre la edad y la FAIVM de mano no-dominante (hombres: $r=-0,65$; mujeres: $r=-0,59)$ y dominante (hombres: $r=-0,71$; mujeres: $r=-0,64$ ). Al correlacionar la FAIVM y la edad en el grupo de 65-70 años, una correlación significativa fue observada en la mano no-dominante (hombres, $r=-0,45$; mujeres, $r=-0,61$ ) y mano dominante (hombres, $r=-0,47$; mujeres, $r=-0,64$ ). En el grupo $\geq 71$ años, la edad tuvo una mayor correlación con la FAIVM de la mano no-dominante (hombres, $r=-0,92$; mujeres, $r=-0,90$ ) y mano dominante (hombres, $r=-0,95$; mujeres, $r=-0,90$ ). Comparada con la mano dominante, la mano no-dominante presentó menores valores de FAIVM en todos los grupos, variando entre $-2,8$ a $-8,9 \%$. Comparadas con los hombres, las mujeres presentaron menor FAIVM en mano dominante y no-dominante, en ambos grupos de edad. Conclusión: La FAIVM disminuye con la edad, especialmente desde los 71 años; es mayor en hombres comparados con mujeres y es mayor en mano dominante comparada con mano no-dominante.

$\longrightarrow$ hile shows an aging pattern and for the year 2025 it is expected that $20.1 \%$ of its adult population will be constituted by older adults ${ }^{1}$. Aging is a complex natural process, implicating psychological and social changes, alongside with physical changes, with a potential negative impact on quality of life ${ }^{2}$. A key issue is the progressive reduction of physical fitness along with a reduction in muscle strength (dynapenia) $)^{3,4}$. Dynapenia may occur with independence from neurologic or muscular diseases ${ }^{4}$ and is associated with the progressive dysfunction of the endocrine, neural, cardiovascular, and musculoskeletal systems, where the reduction of muscle mass, negative changes in mental health, nutritional status, physical inactivity and sedentary behavior contributes to increase the rate of dynapenia ${ }^{4-6}$. This loss of muscle strength negatively affects physical performance and mobility, leading to increased risk of functional dependency, disability, and morbimortality among older adults ${ }^{6-8}$. Therefore, the opportune muscle-strength assessment status of older adults is a key issue, ideally with simple, inexpensive and reliable tests ${ }^{8}$.

Maximal isometric dynamometric handgrip strength is a simple and inexpensive test to assess muscle strength, with high reliability and validity ${ }^{9-12}$ to estimate the functionality in older adults due to their elevated association with the strength and mass of several muscle groups ${ }^{8}$. Also, handgrip strength in older adults is associated with independent-living, quality of life ${ }^{13}$, health ${ }^{14}$, may help to identify population at risk of functional limitations ${ }^{15}$, frailty ${ }^{16}$, falling, morbidity after sur- gery, among others relevant aspects ${ }^{17}$. In addition, a recent study showed a significant association between handgrip strength and several cardiovascular risk factors in Chilean older population ${ }^{18}$.

Internationally populations-based handgrip strength values usually are expressed according to age and sex, while the relationship with handedness has demonstrated contrasting results ${ }^{19,20}$. Usually men exhibit greater handgrip strength compared to women ${ }^{12,14,20}$ and maximal values are achieved during the fourth decade of life ${ }^{21}$, and from there a strong inverse relationship exists between handgrip strength and age ${ }^{22,23}$. Regarding handedness, right-handed subjects are stronger with their right hand, while left-handed subjects show unclear results ${ }^{24}$.

In Chile, reports regarding handgrip strength in older populations are scarce ${ }^{25-27}$, usually employing different measurement equipment and protocols. Considering the important differences between studied populations and methodologies employed for determination of the handgrip strength in older adults, both at internationally ${ }^{28-30}$ and national level ${ }^{25-27}$, critical limitations have emerged regarding its clinical applicability in community-health programs for older adults in Chile, being necessary to count with standardized reference values in view of its potential applicability in public health policies.

In very recent years ${ }^{31,32}$, some studies have emerged demonstrating the importance of handgrip strength and mortality among Chilean older adults. However, most information comes from northern and central regions of Chile, with no 
information from the southern areas. Considering that important differences on health-related variables may exist within a country ${ }^{31,33,34}$, is of key relevance to continue to elaborate standards for grip strength for older adults considering that Chile is a geographically large country. Therefore, due to the limited information regarding maximal voluntary isometric handgrip strength (MVIHS) in older Chilean people from the southern regions, the aim of this study is to describe the MVIHS and its relationship with age, sex, and handedness in those people.

\section{Methods}

\section{Subjects and procedures}

A descriptive, exploratory, cross-sectional study was conducted with community-dwelling older participants of Hispanic descent from an urban area in a southern city in Chile, in the commune of Osorno. The study was conducted in the Laboratory of Human Performance, at the University of Los Lagos. Inclusion criteria required i) being free of dependency risk according to the Functional Diagnosis for Older Adults from the Preventive Medical Exam for Older Adults (EMPAM) by the Chilean Ministry of Health ${ }^{35}$, ii) having non-altered punctuation in the Mini Mental Status Examination test (short form) according to Chilean standards from the EMPAM ${ }^{35}$, iii) being $\geq 65$ years of age, iv) being free of risk according to the Physical Activity Readiness Questionary (PAR-Q) for older adults ${ }^{36}$. Excluded subjects were those with i) blindness, severe hearing loss, upper limb amputation, stroke-related complications or any physical or mental condition that could affect the results of dependent variables. According to these requirements, from 184 participants initially screened only 120 (female, $n=60$; male, $n=60$ ) where included in the study. All subjects were carefully informed about the experimental procedures and about the possible risks and benefits associated with participation in the study and signed an informed consent document before any of the tests were performed. The study was conducted in accordance with the Declaration of Helsinki and was approved by the ethics committee of the Department of Physical Activity Sciences, from the University of Los Lagos.

Standing height $(\mathrm{m})$ and body mass $(\mathrm{kg})$ were assessed according to international standards for anthropometric assessment ${ }^{37}$. Anthropometry comprised stature on a stadiometer (Bodymeter 206, SECA, Germany) and body mass on an electrical scale (BF 100_Body Complete, Beurer, Germany), with precisions of $0.1 \mathrm{~cm}$ and $0.1 \mathrm{~kg}$, respectively. These parameters were assessed prior to the MVIHS test. Subjects were tested while wearing light clothing (shoes were removed). The body mass index (BMI) was calculated $\left(\mathrm{kg} / \mathrm{m}^{-2}\right)$.

\section{Measurement of handgrip strength}

Participants were required to avoid unusual physical activities at least 24 hours before MVIHS measurements, with especial emphasis in activities that may have implicated an unusual high-load for the upper extremities. This requirement was verified with a personal interview at the beginning of the measurement day. To assess MVIHS an adjustable digital dynamometer was used (Jamar ${ }^{\circledR}$, PLUS+, Sammons Preston, Patterson Medical, Illinois, United States). After randomly assigning the order of dominant and non-dominant hand assessment (i.e., handedness was assesses based on previous recommendations $)^{38}$, subjects completed a standardized general and specific familiarization warm-up protocol, consisting of ten submaximal contractions of the forearm muscles (using a squeeze-ball) and three submaximal handgrip attempts (using the digital dynamometer). Then, subjects had three valid attempts to achieve MVIHS for both dominant and non-dominant hands, with two minutes of rest between attempts. For each maximal attempt, subjects were asked to exert five seconds of maximal effort, while receiving standardized verbal motivation. Subjects completed each maximal attempt while seated on a chair in an erect position. The hip, knee, and elbow were flexed to a $90^{\circ}$ angle and the shoulder was abducted and neutrally rotated. The forearm was in a neutral position and the wrist was slightly extended $\left(0^{\circ}\right.$ to $\left.30^{\circ}\right)$. Subjects performed the test with a horizontal cylinder handgrip using the position II on the digital dynamometer, while the evaluator lightly supported this in its base. The best result (expressed in $\mathrm{kg}$ ) of the three valid maximal attempts for each hand was chosen for statistical analysis.

\section{Statistical Analyses}

All values are reported as the mean \pm standard deviation (SD). Normality and homoscedasticity 
assumptions for all data were checked with the Shapiro-Wilk and Levene's tests, respectively. When dependent variables had a non-parametric distribution, logarithmic procedures were conducted. Aside from age, all variables complied with the assumption of homoscedasticity (Levene's test). In the case of age, as the homogeneity of variances assumption is usually not as crucial as other assumptions (in particular in the case of balanced -equal n- designs) ${ }^{39}$, age-related analyses were performed with parametric tests and repeated using nonparametric methods to contrast. As no differences emerged, Pearson's $r$ was used for all correlations. In addition, coefficient of determination $\left(r^{2}\right)$ were employed in order to assess the best suited model (model quality) in relation with the age-related changes in MVIHS. For comparisons between dominant and non-dominant hand stren$\mathrm{gth}$, the $\mathrm{t}$ test for dependent samples was used. For comparison between groups, a one-way ANOVA was performed with a post hoc Fisher LSD test to locate the pairwise differences between the mean values. The $\alpha$ level was set at $\mathrm{p} \leq 0.05$ for statistical significance. All statistical calculations were per- formed using the STATISTICA statistical package (Version 8.0; StatSoft Inc., Tulsa, OK, USA). For comparisons between frail and non-frail older adults, we considered the cut-points values of MVIHS stablished previously according to sex and body mass index ${ }^{40}$.

\section{Results}

High intra-class correlation coefficients were observed for MVIHS measurements (i.e., 0.92 and 0.95 for dominant and non-dominant hand, respectively), demonstrating high reliability of measurement. For males, $25^{\text {th }}, 50^{\text {th }}$ and $75^{\text {th }}$ percentile values of MIVHS were $28.3 \mathrm{~kg}, 32.9 \mathrm{~kg}$, and 37.3 $\mathrm{kg}$, respectively. For females, the values were 14.9 $\mathrm{kg}, 21.5 \mathrm{~kg}$ and $25.8 \mathrm{~kg}$, respectively. The rest of the results are reported in Table 1, according to handedness, age and sex group.

In men and women a correlation was observed between age, non-dominant (men: $r=-0.65 ;-0.64$ Spearman; women: $\mathrm{r}=-0.59$; -0.58 Spearman) and dominant (men: $r=-0.71 ;-0.67$ Spearman;

Table 1. Description of dependent variables according to age and sex groups

\begin{tabular}{|c|c|c|c|c|c|c|}
\hline & \multicolumn{2}{|c|}{ Group 65-70 y } & \multicolumn{2}{|c|}{ Group $\geq 71$ y } & \multicolumn{2}{|c|}{ Total } \\
\hline & $\begin{array}{c}\text { Men } \\
(n=30)\end{array}$ & $\begin{array}{l}\text { Women } \\
(n=30)\end{array}$ & $\begin{array}{c}\text { Men } \\
(n=30)\end{array}$ & $\begin{array}{l}\text { Women } \\
(n=30)\end{array}$ & $\begin{array}{c}\text { Men } \\
(n=60)\end{array}$ & $\begin{array}{l}\text { Women } \\
(n=60)\end{array}$ \\
\hline Age (years) & $67,8 \pm 1,8$ & $67,9 \pm 1,8$ & $77,3 \pm 4,1$ & $77,0 \pm 4,4$ & $72,5 \pm 5,7$ & $72,4 \pm 5,7$ \\
\hline Body mass (kg) & $76,9 \pm 14,3$ & $73,2 \pm 16,5$ & $76,2 \pm 12,9$ & $68,5 \pm 14,8$ & $76,5 \pm 13,5$ & $70,9 \pm 15,7$ \\
\hline Height (m) & $1,59 \pm 0,10$ & $1,52 \pm 0,12$ & $1,60 \pm 0,10$ & $1,51 \pm 0,12$ & $1,59 \pm 0,10$ & $1,52 \pm 0,12$ \\
\hline Body mass index $\left(\mathrm{kg} / \mathrm{m}^{2}\right)$ & $30,0 \pm 2,4$ & $31,3 \pm 2,9$ & $29,7 \pm 2,5$ & $29,6 \pm 2,9$ & $29,9 \pm 2,4$ & $30,4 \pm 3,0$ \\
\hline $\begin{array}{l}\text { Underweight (n) } \\
\text { Normoweight (n) } \\
\text { Overweight (n) } \\
\text { Obesity (n) }\end{array}$ & $\begin{array}{r}0 \\
5 \\
20 \\
5\end{array}$ & $\begin{array}{r}0 \\
4 \\
16 \\
10\end{array}$ & $\begin{array}{r}1 \\
7 \\
18 \\
4\end{array}$ & $\begin{array}{r}0 \\
10 \\
17 \\
3\end{array}$ & $\begin{array}{r}1 \\
12 \\
38 \\
9\end{array}$ & $\begin{array}{r}0 \\
14 \\
33 \\
13\end{array}$ \\
\hline $\begin{array}{l}\text { MVIHS dominant hand }(\mathrm{kg}) \\
\text { Range (minimum-maximum) } \\
\text { 95\% confidence interval }\end{array}$ & $\begin{array}{l}36,5 \pm 7,2^{b} \\
21,2-50,2 \\
33,8-39,2\end{array}$ & $\begin{array}{c}23,2 \pm 7,9^{d} \\
6,5-38,5 \\
20,2-26,1\end{array}$ & $\begin{array}{l}30,2 \pm 6,4^{c} \\
17,9-43,7 \\
27,8-32,6\end{array}$ & $\begin{array}{l}19,0 \pm 6,8 \\
5,4-33,4 \\
16,5-21,6\end{array}$ & $\begin{array}{l}33,3 \pm 7,5 \\
17,9-50,2 \\
31,4-35,3\end{array}$ & $\begin{array}{c}21,1 \pm 7,6 \\
5,4-38,5 \\
19,1-23,1\end{array}$ \\
\hline $\begin{array}{l}\text { MVIHS non-dominant hand (kg) } \\
\text { Range (minimum-maximum) } \\
\text { 95\% confidence interval }\end{array}$ & $\begin{array}{l}34,3 \pm 8,3^{b} \\
15,4-52,0 \\
31,2-37,4\end{array}$ & $\begin{array}{l}21,3 \pm 7,6 \\
4,1-35,2 \\
18,5-24,2\end{array}$ & $\begin{array}{l}28,2 \pm 6,4^{c} \\
16,5-42,9 \\
25,9-30,6\end{array}$ & $\begin{array}{l}18,1 \pm 6,0 \\
8,1-30,8 \\
15,9-20,4\end{array}$ & $\begin{array}{l}31,3 \pm 8,0 \\
15,4-52,0 \\
29,2-33,3\end{array}$ & $\begin{array}{c}19,7 \pm 7,0 \\
4,1-35,2 \\
17,9-21,5\end{array}$ \\
\hline MVIHS difference between hands (\%) & $-6,9 \pm 5,9^{a}$ & $-8,9 \pm 7,1^{a}$ & $-6,4 \pm 4,8^{a}$ & $-2,8 \pm 12,1^{a}$ & $-6,7 \pm 5,3^{a}$ & $-5,8 \pm 10,3^{a}$ \\
\hline Left-handed (n) & 2 & 2 & 2 & 1 & 4 & 3 \\
\hline
\end{tabular}

alower ( $p<0.05)$ compared to dominant hand. ${ }^{b}$ greater $(p<0.05)$ compared to women 65-70 y and men/women $\geq 71$ y. cgreater $(p<0.05)$ compared to women $65-70 y \geq 71$ y. ${ }^{d}$ greater $(p<0.05)$ compared to women $\geq 71$ y. MVIHS: maximal voluntary isometric handgrip strength. 
women: $r=-0.64 ;-0.60$ Spearman) MVIHS. In addition, in the combined sample of men and women a correlation between age and non-dominant $(\mathrm{r}=-0.49 ;-0.48$ Spearman $)$ and dominant $(\mathrm{r}=-0.52 ;-0.49$ Spearman $)$ MVIHS was observed.

When age and MVIHS were correlated in the 65-70 y group, a significant correlation was observed in the non-dominant (men, $\mathrm{r}=-0.45$; women, $r=-0.61$ ) and dominant hand (men, $r=-0.47$; women, $r=-0.64)$. In the $\geq 71$ group, a significant correlation was also observed in the non-dominant (men, $r=-0.92$; women, $r=-0.90$ ) and dominant hand (men, $\mathrm{r}=-0.95$; women, $\mathrm{r}=-0.90)$.

In the whole sample of males, the coefficient of determination indicated a significant decline in MVIHS with increased age $(-0.56 \pm 0.07 \mathrm{~kg}$ per year; $p<0.0001)$, as wheel as in the whole sample of females $(-0.50 \pm 0.07 \mathrm{~kg}$ per year; $\mathrm{p}<0.0001)$, with no significant difference between males and females $(\mathrm{p}=0.52)$.

Comparisons between groups revealed that i) compared to the dominant hand, the non-dominant hand showed lower MVIHS in all groups, varying between -2.8 to $-8.9 \%$ (Table 1 ); ii) compared to men, women exhibited lower dominant and non-dominant MVIHS in both age groups (Table 1); iii) compared to men and women $\geq 71$ years old, men and women in the 65-70 age group showed greater dominant and non-dominant MVIHS compared to their respective sex group counterpart (Table 1).

The differences in MVIHS between genders and age groups is graphically depicted in figure 1. Significant differences $(\mathrm{p}<0.05)$ in MVIHS were observed between all groups (Figure 1, upper portion). In addition, when MVIHS was expressed in relation to body mass (figure 1, lower portion), significant differences $(p<0.05)$ in MVIHS were also observed between all groups. Moreover, body mass predicted $30 \%$ of MVIHS values. When the body mass index was correlated with MVIHS, although a significant relationship was observed $(\mathrm{p}<0,001)$, the coefficient of determination was rather low for both dominant $\left(\mathrm{r}^{2}=0.19\right)$ and non-dominant hands $\left(r^{2}=0.17\right)$ in the whole group of older adults.

When older adults were divided into frail and non-frail groups according to their respective age and sex groups, as expected, for each of the four groups significant $(\mathrm{p}<0.05)$ differences

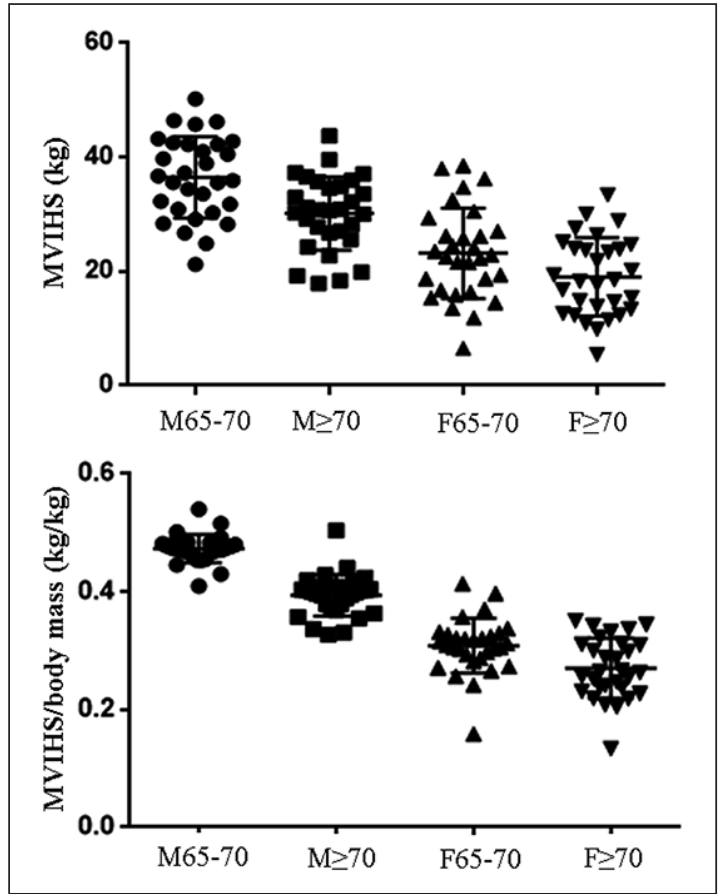

Figure 1. Maximal voluntary isometric handgrip strength (MVIHS) in males (M) and females (F) older adults aged 65-70 years or over 70 years. Note: significant differences $(p<0.05)$ in MVIHS were detected between all groups.

were observed between frail and non-frail older adults for MVIHS (Figure 2) when the values of both dominant and non-dominant hands were combined. Moreover, when the dominant and non-dominant MVIHS was compared in frail and non-frail older adults, greater $(\mathrm{p}<0.05)$ values of strength were observed in the dominant hand (Figure 3 ). In addition, for a given hand (dominant; non-dominant), greater MVIHS values were observed in non-frail older adults as compared to their frail counterparts (Figure 3).

\section{Discussion}

The aim of this study was to describe MVIHS and its relationship with age, sex, and handedness in older adults. The main results indicated that MVIHS declined with age, is greater in men compared to women, and is greater in the dominant compared to the non-dominant hand.

The MVIHS may be associated with health 


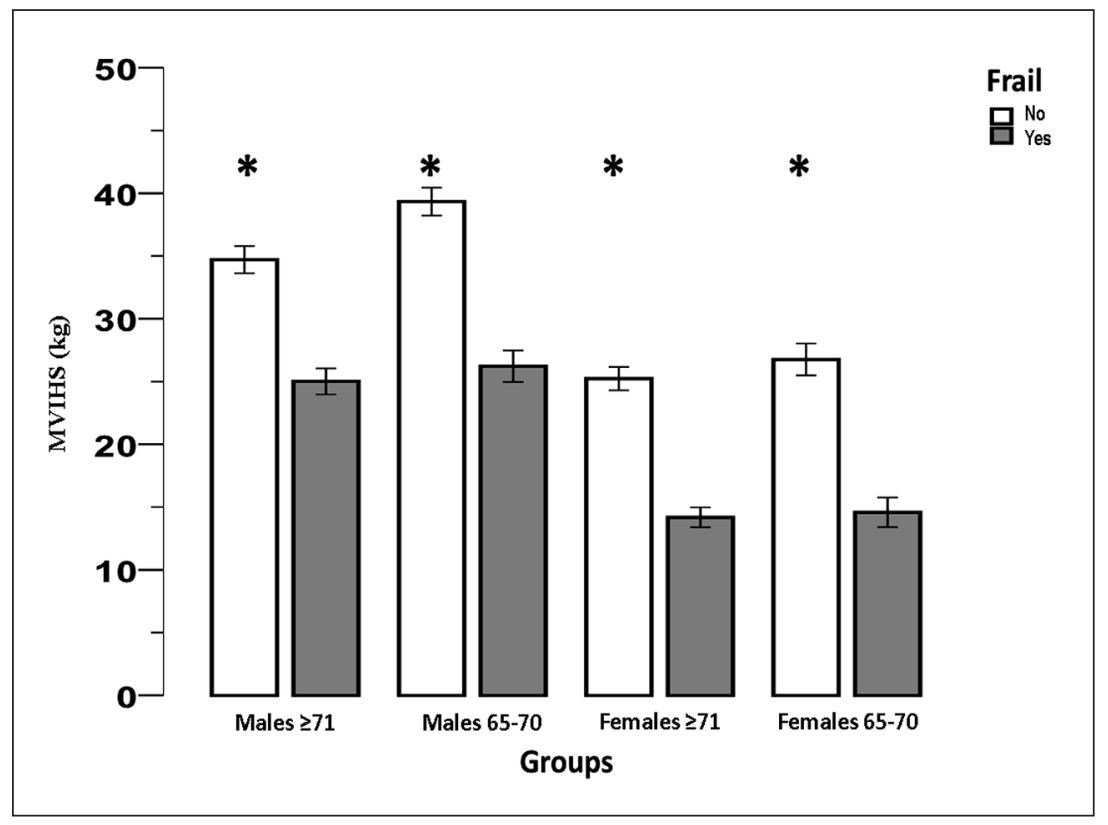

Figure 2. Maximal voluntary isometric handgrip strength (MVIHS) in frail and non-frail older adults according to sex and age. *denotes significant $(p<0.05)$ difference between frail and non-frail groups for a given sex-age group.

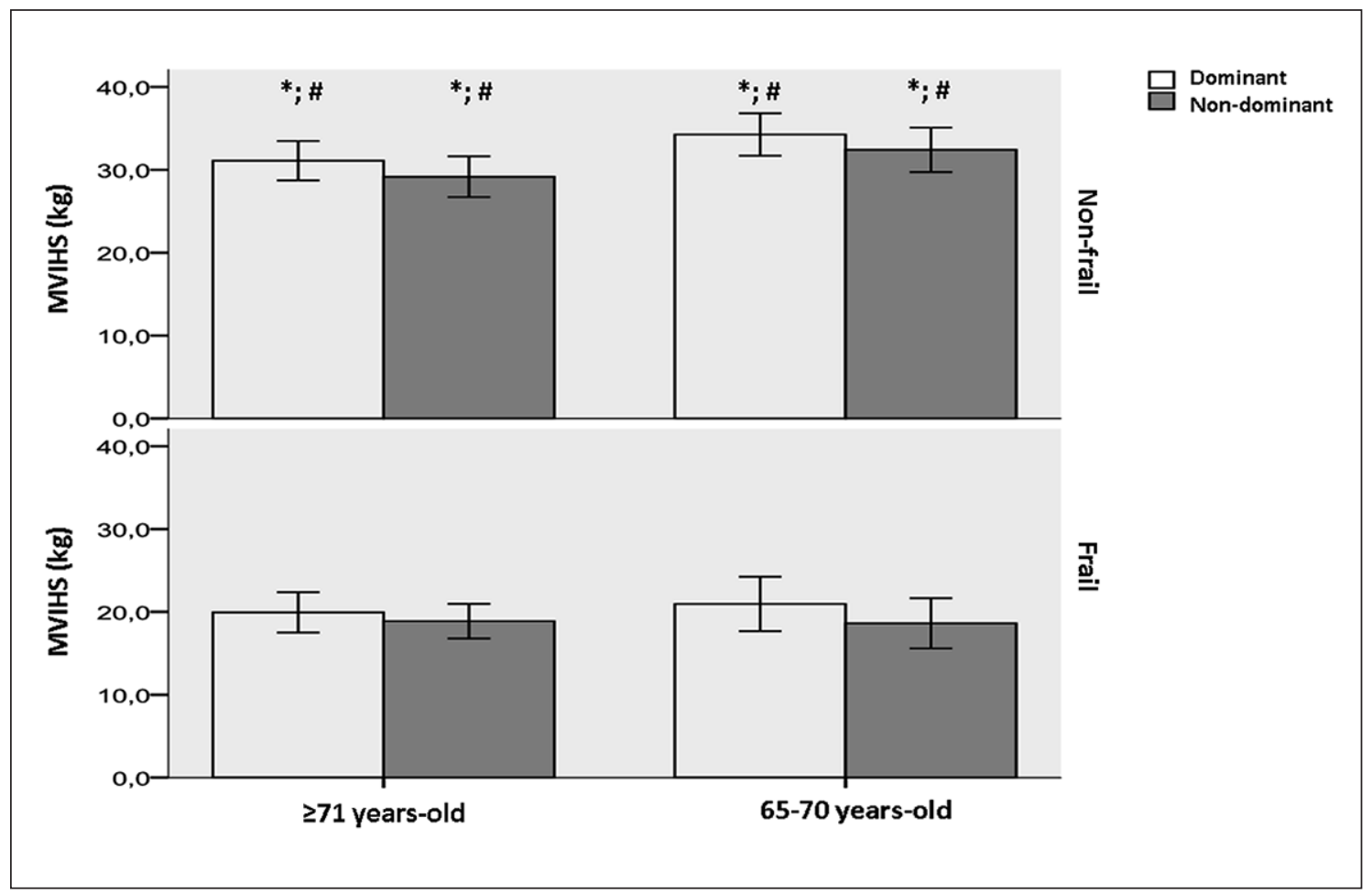

Figure 3. Maximal voluntary isometric handgrip strength (MVIHS) of frail and non-frail older adults according to handedness and age. *denotes significant $(p<0.05)$ difference between hands for a given age-group; \#denotes significant difference between frail and non-frail groups for a given hand. 
and functional status in older populations ${ }^{14-17}$ and may be affected by several factors ${ }^{5,6,41}$. Our results indicate that age was one of these factors, as it was inversely associated with MVIHS, corroborating previous observations ${ }^{22,42}$. Similar to previous finding $\mathrm{s}^{21}$, the decline in MVIHS was observed in both men and women. Our results also showed that the decline in MVIHS is similar in males and females with age. This result is comparable with previous reports ${ }^{343-45}$, suggesting that utmost care is needed in the oldest populations to reduce the probability of functional dependency due to reduced muscle strength.

In relation to dominance, our results indicated a greater MVIHS in the dominant hand compared to the non-dominant hand. This observation is relatively common ${ }^{27,28}$. More so, our results indicated a difference in MVIHS between the dominant and non-dominant hand of up to $~ 9 \%$ of the study cohort, comparable in magnitude $(\sim 10 \%)$ to values previously reported ${ }^{27,28}$. Although differences in MVIHS between dominant and non-dominant hands might depend on whether subjects are lefthand or right-hand dominant (i.e., right-handed subjects usually exhibit greater MVIHS in the dominant hand, while left-handed subjects show conflicting results) ${ }^{24}$, our sample was comprised mainly of right-handed subjects. Although a previous large-cohort study in Chile have described MIIHS values for Chilean older adults in their dominant hand ${ }^{32}$, our results expand previous findings, incorporating measures for both dominant and non-dominant hands. Such findings are of relevance, considering that during daily living older adults may use both hands to perform their activities.

In relation to sex, it is relatively common to observe that men exhibit greater MVIHS compared to women ${ }^{9-12,14-17,19,20,46,47}$, an observation corroborated by our results. Also, our results indicate that the difference between men and women remains constant up to an advanced age (i.e., $\geq 71 \mathrm{y}$ ), which had been previously observed in an older Chilean population ${ }^{27}$. Moreover, differences between men and women were observed in both dominant and non-dominant hands, meaning than sex-related differences in MVIHS might be common to contralateral limbs. In addition, our results indicated that differences between males and females remain even after adjusting for body mass (Figure 1). Further research is needed to corroborate if this can be extrapolated to lower limb muscles of older men and women.

Although few studies have been conducted in Chile focusing on the MVIHS of older adults and its relation with health ${ }^{25,26}$, the results from this study conducted in a southern region, are very similar to previous reports for older men and women from other regions of Chile ${ }^{27,32}$. This strengthens the external validity of previous observations and provides support for the recommendation of this measurement at a preventive level for Chilean older adults in the clinical practice at national level by the Chilean Ministry of Health ${ }^{35}$.

A potential limitation of the study is the lack of physiological measures (e.g., blood glucose, HOMA, plasma free fatty acids, blood pressure) and functional performance (e.g., up-and-go test). Future studies may aim to establish a relationship between cardio metabolic risk markers, functional performance and grip strength in Chilean older adult population. Moreover, the assessment of body composition, especially muscle mass, in future studies may help to better understand the relationship between MVIHS and the variables analyzed in the current study. Although the present work constitutes a starting point to establish normative values of MVIHS in Chilean older adults in the south of the country, more studies with larger samples are required.

\section{Conclusion}

In conclusion, MVIHS declined with age in older adults, with a similar rate in males and females, MVIHS is greater in men compared to women, and MVIHS is greater in the dominant compared to the non-dominant hand.

Acknowledgement: We thank all participants who volunteered for this work.

\section{References}

1. INE (Instituto Nacional de Estadística). Población y sociedad. Aspectos demográficos. Chile; 2008.

2. Bauer JM, Sieber CC. Sarcopenia and frailty: a clinician's controversial point of view. Exp Gerontol 2008; 43 (7): 674-8.

3. Bohannon RW, Magasi S. Identification of dynapenia 
in older adults through the use of grip strength t-scores. Muscle Nerve 2015; 51 (1): 102-5.

4. Clark BC, Manini TM. What is dynapenia? Nutrition 2012; 28 (5): 495-503.

5. Paddon-Jones D, Short KR, Campbell WW, Volpi E, Wolfe RR. Role of dietary protein in the sarcopenia of aging. Am J Clin Nutr 2008; 87 (5): 1562S-6S.

6. Thompson DD. Aging and sarcopenia. J Musc Neur Interactions 2007; 7 (4): 344-5.

7. Rantanen T, Harris T, Leveille SG, Visser M, Foley D, Masaki K, et al. Muscle strength and body mass index as long-term predictors of mortality in initially healthy men. J Gerontol A Biol Sci Med Sci 2000; 55 (3): M16873.

8. Cruz-Jentoft AJ, Baeyens JP, Bauer JM, Boirie Y, Cederholm T, Landi F, et al; European Working Group on Sarcopenia in Older People. Sarcopenia: European consensus on definition and diagnosis: Report of the European Working Group on Sarcopenia in Older People. Age Ageing 2010; 39 (4): 412-23.

9. Mathiowetz V, Kashman N, Volland G, Weber K, Dowe M, Rogers S. Grip and pinch strength: normative data for adults. Arch Phys Med Rehabil 1985; 66 (2): 69-74.

10. Mathiowetz V. Comparison of Rolyan and Jamar dynamometers for measuring grip strength. Occup Therapy Inter 2002; 9 (3): 201-9.

11. Smidt N, van der Windt DA, Assendelft WJ, Mourits AJ, Devillé WL, de Winter AF, et al. Interobserver reproducibility of the assessment of severity of complaints, grip strength, and pressure pain threshold in patients with lateral epicondylitis. Arch Phys Med Rehabil 2002; 83 (8): 1145-50.

12. Mijnarends DM, Meijers JM, Halfens RJ, ter Borg S, Luiking YC, Verlaan S, et al. Validity and reliability of tools to measure muscle mass, strength, and physical performance in community-dwelling older people: a systematic review. J Amer Med Directors Assoc 2013; 14 (3): 170-8.

13. Sayer AA, Syddall HE, Martin HJ, Dennison EM, Roberts $\mathrm{HC}$, Cooper C. Is grip strength associated with health-related quality of life? Findings from the Hertfordshire Cohort Study. Age Ageing 2006; 35(4): 409-15.

14. Cooper R, Kuh D, Cooper C, Gale CR, Lawlor DA, Matthews F, et al; FALCon and HALCyon Study Teams. Objective measures of physical capability and subsequent health: a systematic review. Age Ageing 2011; 40 (1): 14-23

15. Sallinen J, Stenholm S, Rantanen T, Heliovaara M, Sainio P, Koskinen S. Hand-grip strength cut points to screen older persons at risk for mobility limitation. J Am Geriatr Soc 2010; 58 (9): 1721-6.
16. Syddall H, Cooper C, Martin F, Briggs R, Aihie Sayer A. Is grip strength a useful single marker of frailty? Age Ageing 2003; 32 (6): 650-6.

17. Angst F, Drerup S, Werle S, Herren DB, Simmen BR, Goldhahn J. Prediction of grip and key pinch strength in 978 healthy subjects. BMC Musculoskelet Disord 2010; 11: 94.

18. Farías-Valenzuela C, Pérez-Luco C, Ramírez-Campillo R, Álvarez C, Castro-Sepúlveda M. [Oxygen peak consumption is a better predictor of cardiovascular risk than handgrip strength in older Chilean women]. Rev Esp Ger Geron 2018; 53 (3): 141-4.

19. Massy-Westropp NM, Gill TK, Taylor AW, Bohannon RW, Hill CL. Hand Grip Strength: age and gender stratified normative data in a population-based study. BMC Research Notes 2011; 4: 127.

20. Yorke AM, Curtis AB, Shoemaker M, Vangsnes E. Grip strength values stratified by age, gender, and chronic disease status in adults aged 50 years and older. J Geria Phys Therapy 2015; 38 (3): 115-21.

21. Daly RM, Rosengren BE, Alwis G, Ahlborg HG, Sernbo I, Karlsson MK. Gender specific age-related changes in bone density, muscle strength and functional performance in the elderly: a-10 year prospective population-based study. BMC Geriatrics 2013; 13: 71.

22. Kallman DA, Plato CC, Tobin JD. The role of muscle loss in the age-related decline of grip strength: cross-sectional and longitudinal perspectives. J Gerontology 1990; 45 (3): M82-8.

23. Peters MJ, van Nes SI, Vanhoutte EK, Bakkers M, van Doorn PA, Merkies IS, et al; PeriNomS Study group. Revised normative values for grip strength with the Jamar dynamometer. J Peripheral Nerv System: JPNS 2011; 16 (1): 47-50.

24. Bohannon RW. Grip strength: a summary of studies comparing dominant and nondominant limb measurements. Percept Mot Skills 2003; 96 (3 Pt 1): 728-30.

25. Arroyo P, Lera L, Sánchez H, Bunout D, Santos JL, Albala C. [Anthropometry, body composition and functional limitations in the elderly]. Rev Med Chile 2007; 135 (7): 846-54.

26. Pino J, Mardones M, Díaz C. Relación entre antropometría de mano y la circunferencia de pantorrilla con el índice de masa corporal en ancianos autovalentes. Rev Chil Nutr 2011; 38 (1): 23-9.

27. Guede Rojas F, Chirosa Ríos LJ, Vergara Ríos C, Fuentes Contreras J, Delgado Paredes F, Valderrama Campos MJ. [Association of grip strength with gender age and handedness in 116 older people]. Rev Med Chile 2015; 143 (8): 995-1000. 
28. Crosby CA, Wehbe MA, Mawr B. Hand strength: normative values. J Hand Surg 1994; 19(4): 665-70.

29. Werle S, Goldhahn J, Drerup S, Simmen BR, Sprott H, Herren DB. Age- and gender-specific normative data of grip and pinch strength in a healthy adult Swiss population. J Hand Surg, European Volume 2009; 34 (1): 76-84.

30. Roberts HC, Denison HJ, Martin HJ, Patel HP, Syddall $\mathrm{H}$, Cooper $\mathrm{C}$, et al. A review of the measurement of grip strength in clinical and epidemiological studies: towards a standardised approach. Age Ageing 2011; 40 (4): 4239.

31. Leong DP, Teo KK, Rangarajan S, López-Jaramillo P, Avezum A, Orlandini A, et al. Prognostic value of grip strength: findings from the Prospective Urban Rural Epidemiology (PURE) study. Lancet 2015; 386: 266-73.

32. Lera L, Albala C, Leyton B, Márquez C, Angel B, Saguez $\mathrm{R}$, et al. Reference values of hand-grip dynamometry and the relationship between low strength and mortality in older Chileans. Clin Interv Aging 2018, 13: 317-324.

33. Rodríguez F, Morant N, Santibáñez F. Nutritional supplement intake in gymnasium, consumer profile and charateristics of their use. Rev Chil Nutr 2011; 38 (2): 157-66.

34. Gallardo-Fuentes F, Gallardo-Fuentes J, Ruiz-Aguilar C, Ramírez-Campillo R, Rodríguez-Rodríguez F. [Characterization of nutritional supplements consumption in physically active population in gyms of southern Chile]. Diaeta (B. Aires) 2015; 33 (151): 14-20.

35. MINSAL. Manual de Aplicación del Examen de Medicina Preventiva del Adulto Mayor EMPAM. Gobierno de Chile, 2008.

36. Cardinal BJ, Esters J, Cardinal MK. Evaluation of the revised physical activity readiness questionnaire in older adults. Med Sci Sports Exerc 1996; 28 (4): 468-72.

37. Marfell-Jones M, Olds T, Stewart A, Carter L. International standards for anthropometric assessment. Potchefstroom, South Africa; 2006.

38. Oldfield RC. The assessment and analysis of handedness: the Edinburgh inventory. Neuropsychologia 1971; 9(1): 97-113.

39. Glass GV, Hopkins KD. Statistical methods in education and psychology. 3rd ed. Needham Heights, MA; 1996.

40. Gary R. Evaluation of frailty in older adults with cardiovascular disease: incorporating physical performance measures. J Cardiovas Nursing 2012; 27 (2): 120-31.

41. Nelson ME, Rejeski WJ, Blair SN, Duncan PW, Judge JO, King AC, et al. Physical activity and public health in older adults: recommendation from the American College of Sports Medicine and the American Heart Association. Circulation 2007; 116 (9): 1094-105.

42. Desrosiers J, Bravo G, Hebert R, Dutil E. Normative data for grip strength of elderly men and women. Am J Occup Ther 1995; 49 (7): 637-44.

43. Stenholm S, Harkanen T, Sainio P, Heliovaara M, Koskinen S. Long-term changes in handgrip strength in men and women--accounting the effect of right censoring due to death. J Gerontol A Biol Sci Med Sci 2012; 67 (10): 1068-74.

44. Kerckhofs AG, Vandewoude MF, Mudde AN. [Measuring the handgrip strength of geriatric patients]. Tijdschrift voor Gerontologie en Geriatrie 2014; 45 (4): 197-207.

45. Proctor DN, Fauth EB, Hoffman L, Hofer SM, McClearn GE, Berg S, et al. Longitudinal changes in physical functional performance among the oldest old: insight from a study of Swedish twins. Aging Clin Experi Res 2006; 18 (6): 517-30.

46. Bohannon RW, Peolsson A, Massy-Westropp N, Desrosiers J, Bear-Lehman J. Reference values for adult grip strength measured with a Jamar dynamometer: a descriptive meta-analysis. Physiotherapy 2006; 92 (1): 11-5.

47. Mancilla SE, Ramos FS, Morales BP. [Association between handgrip strength and functional performance in Chilean older people]. Rev Med Chile 2016; 144(5): 598-603. 